\author{
ALEXANDER SHUMILIN, \\ Bishkek Bible College (Kant, Kyrgyzstan) \\ e-mail: bukyrg59@gmail.com,ORCID 0000-0002-3087-5292
}

\title{
BIBLICAL IMAGE OF TRUE SONSHIP IN THE EPISTLE TO THE HEBREWS
}

\begin{abstract}
The theme of sonship is one of the central themes in the New Testament. Sometimes it can be traced explicitly, but more often indirectly. True sonship involves obedience to parents and, as a result, leads to parental blessing. This is the truth the writer of the Epistle to the Hebrews wanted to convey to his readers. He did this using the example of Jesus Christ as the only begotten Son of God. He, being the true the Son, consubstantial to Father, showed complete and unconditional obedience, despite the strongest temptations and incredible suffering. His obedience to the Father not only led Him to glory, not only showed the holy essence and wisdom of God Himself, but also led and leads to the glory of His followers. Called by God and saved by Him, having become His children, in obedience to God, must become like the Son of God, as the Firstborn. Only a consecrated life leads one to blessings. The foundation of such a life is faith in Jesus Christ and living according to His commandments. Apostasy from Him and transgression of God's commandments deprives a person of blessing and grace.

Most scholars of the Epistle to the Hebrews place more emphasis on the Sonship of Christ and His High Priesthood, and this is important to show the members of the community the superiority of what they have in Jesus over Judaism. However, there are few who emphasize the obedience of the Son of God to His Heavenly Father and its consequences, as well as an example of this obedience for followers of Jesus Christ. The author of the Epistle wants to show that not only the confession of Jesus Christ as Lord, but also obedience is a guarantee of blessing. It was the disobedience of the community members that led them to God's punishment, caused a crisis of faith, and led to apostasy. A true son is an obedient son.

If there are any mentions of Christ's obedience and His example for His followers in the studies of various authors, then they are very short and local. Therefore, the task of this study is a deeper study of the Epistle within the framework of this topic.
\end{abstract}

Key words: Epistle to the Hebrews; the theme of obedience to Heavenly Father; Heavenly heritage; Promises to obedient children of God.

\section{Introduction}

Most commentators of the Epistle to the Hebrews have traditionally emphasized the high priesthood of Jesus Christ. And this is not surprising, because out of thirteen chapters of this book, nine are devoted to this topic. Researchers in recent years, in particular A. L.B. Peeler (2011) and S.D. Mackie (2007), consider the theme of the sonship of Jesus, as well as the sonship of His followers, to be central to the Epistle. They show how the sonship of the children of God is related to the sonship of Jesus Christ and what advantages the followers of the Messiah have over the followers of Judaism. In their opinion, the author of the Epistle deliberately develops this topic in order to bring readers out of a state of apostasy and restore their faith in the Son of God.

The author of this article focuses not only on the sonship of Jesus and His followers, but especially on their obedience to the heavenly Father and, as a consequence, the consequences of this obedience.

The aim of the study is to show that the author of Hebrews wants to reflect not only the heavenly sonship of Jesus and His followers, but also the importance of obedience to God.
Research methods

Within the framework of this study, a structural analysis of the Epistle was carried out, as well as hermeneuticexegetical studies of various passages.

\section{Results and Discussion}

The Epistle to the Hebrews was most likely written in the late 60s of the 1st century AD (Lopukhin, 1987: 432; Guthrie, 1996: 543; Carson, 2005: 608). There is a number of evidences for this. First, it is reliably known that Clement of Rome knew about this letter. He refers to it in his letter to the Corinthians A.D. 96. (Lane, 1991: Ixx-Ixxi; Guthrie, 1996: 540; Carson, 2005: 605). Second: in the letter, the author says that he wants to visit the community with Timothy (13:23), presumably a collaborator of the Apostle Paul, who died a martyr's death in A.D. 80/81. (Ebi, 1989: 287). Third, the author contrasts the priesthood of Christ with the Jewish priesthood associated with the Levitical ministry. The writer speaks of the Levitical ministry in the present tense $(7: 8 ; 9: 6-7,9,13 ; 13: 10)$. This means that the temple, most likely, has not yet been destroyed. A weighty argument for such a dating is the still ongoing offering of sacrifices 10: 1-3 during the writ- 
ing of the Epistle (as you know, after the destruction of the temple, sacrifice became impossible). Fourth: v. 2: 3, which is often cited in favor of the later writing of the Epistle, actually cannot give us much specific information about the author, since the "second generation" can be understood not chronologically, but genealogically (Carson, 2005: 605) ... Fifth: The Christology in Hebrews 1: 24 , which some believe was formed only in the 75-90s, is reflected in other Epistles written before the year 70 (Attridge, 1989: 9, 40; see also Carson, 2005: 607-608). Sixth, the information in v. 13: 7 is also not enough to lean towards a later time of writing, since the founding of any first church was associated with difficulties and persecution, and mentors could die already at the stage of the community's beginning.

The message was addressed to the community, which consisted entirely or largely of Jews. About this speak: 1) the numerous quotes from Old Testament; 2) a detailed description of the Levitical and temple ministry, as well as a comparison of Jesus Christ with all Jewish authorities. It is unlikely that such information in the letter was so important and interesting to pagan Christians who experienced great problems in their faith. If the faith of the Gentiles in Christ were questioned, the author would use other arguments. Perhaps there were pagans in the community who doubted Christ. In this case, the author is not worried about their conversion to Judaism, but about their apostasy and sinful way of life (Attridge, 1989: 12-13). And in this situation, he does not need to talk about Jewish values.

The community is most likely raised in JewishHellenistic traditions (Lane). This can be evidenced by the mention of angels in 2: 1-4 as mediators of the transmission of God's law and the comparison of Jesus with Moses in 3: 1-6. This can be evidenced by the author's use of the LXX text, as well as the high Greek rhetoric of the Message (H.W. Attridge has a lot of information about the rhetoric of the Epistle). These circumstances are not in favor of the Palestinian (Jerusalem community). It is not known whether Timothy, referred to in the Epistle (13:23), was known to the Roman community. Out of the other New Testament books it is not known whether the metropolitan community participated in donations for the saints in Palestinian. But the author's mention of the generosity of the community (Hebrews 6: 9-12 cf. 1 Cor. 8: 1-7 and 1 Thess. 1: 3) may testify in favor of the Achaean or Macedonian roots of the community. It is known, these communities experienced persecution already at the beginning of their foundation (Acts 17: 1-9; 1 Thess. 2: 13-16; 3: 1-4; 2 Thess. 1: 1-10; Acts 18: 12-17), and therefore in the Hebrews 10: $32-34$ could to describe their past.

The Epistle was written to a community that was experiencing persecution. We find the confirmation for this conclusion in Hebrews 10: 32-39; 11: 35-40; 12: 4-12 (es.12: 11); 13: 3. It follows from these passages that the community has suffered at some point in the past (and the author reminds them that it was enduring in the past). At the same time, the author points out that members of the community should with dignity and patience endure new sufferings, looking at the heroes of faith and Jesus Christ Himself (Thompson, 2008: 17). Moreover, the persecutions were carried out through the fault of the believers themselves and were God's punishment (12: 4-11).

Who persecuted the believers: fellow tribesmen Jews or pagans, is unknown. One thing is clear, persecution was primarily a consequence of God's punishment for sins (12: 4-11).
As a result of persecution, some members of the community probably abandoned their faith in Christ and returned to the Jewish system of values, became hardened and took the path of sin (Lopukhin, 1987: 433; Mackie, 2007: 114).

In connection with the apostasy of the Jews, as well as to strengthen the followers of Christ in the faith, the author writes this letter (Lane, 1991: ci - cii). In it, he shows the superiority of Christ and his values over Judaism and his system of values. Jesus is higher than Angels, higher than prophets. His priesthood is higher than the earthly. $\mathrm{He}$ is the Son of God. Everything that God does (in particular - speaks), He does in the Son and through the Son (Lane, 1991: xlix - I). The promises to His followers are much greater than the promises made to the followers of Moses. The author calls on weakened Christians to stick to their confession (Hebrews 4:14 and 10:23), and apostates to return to the path of faith in Jesus Christ as the Son of God and High Priest (Scott Mackie points out the importance of two key passages in this regard $-4: 14$ and 10:23). The author reminds readers and listeners that, as children of God, they must walk the path of faith, humility and obedience. Jesus Christ - the Son of God is an example for them (Mackie, 2007: 114129). Jesus' life of obedience to heavenly Father brought $\mathrm{Him}$ to heavenly and earthly glory. Making the children of God like the Son of God will lead them to glory. This is evidenced by the structure of the Epistle.

Let's pay attention to chiasm:

A1. God's grace (ca/riti) 2: 9

B1. The glory of the saved and their sonship (e'kklhsi /a) 2: 10-13

C1. Punishing Children for Sins 12: 4-11

D. Observe that no one is deprived of the grace of God (ca /ritov) 12:15

C2. Esau's Punishment 12: 15b-17

B2. Glory to the Children of God (e'kklhsi /a) 12: 22-28a

\section{A2. Let's keep God's grace (ca /rin) 12: 28b}

The word e'kklhsi /a is used only twice in the epistle to the Hebrews and both times in relation to the children of God, to the family of God. The parallelism in 2:12, the context of chapter 12, and also 3: 1-6 lead to the conclusion that the house of God, the family of God, made up of the children of God (Jesus' brothers), is the Church that shares glory with Christ. Moreover, Jesus, as the Son of God and at the same time a Brother, intercedes for His brothers (2: 11-12 and 2: 15-18). This is where the theme of the High Priesthood begins: within the framework of the grace of God, within the framework of the Church, within the framework of God's sonship. Grace (the ca /riv word used in chiasm) is the only source of salvation and a prerequisite for entering the Church. Grace is given by God (2: 9) and therefore needs to be kept (12: 28b). The absence (u; stere /w) of grace (see 4: 14-16) leads to the loss of peace with God and loss of communion with Him (3: 7-4: 14).

An important issue for the Jews was their involvement with the Israeli people and their identity with them. Therefore, Israel's rejection of their fellow tribesmen, who became Christians, could be one of the reasons for the return of those to Judaism. In this regard, it is important to trace the train of thought of the author of the letter: the acceptance of Christ by the Jews as the Son of God 
makes them part of God's family (introduces them to glory and peace); falling away from Christ and returning to Judaism will return them the disposition of the Jews, but deprive them of God's glory, will cast them out of God's family. In this regard, Jewish Christians need to make their choice: to be pleasing to God and at the same time be ready to suffer, or to return to Judaism, which never helped Israel to become closer to God (chap. 7-9), and at the same time to avoid persecution.

There are many paraenetic passages (calls and exhortations) in the Epistle, each of which is preceded by a description of the exalted position of Christ. The first exhortation (2: 1-4) follows by the description of Christ as the Son of God and His superiority over angels and prophets (1: 1-14), the second exhortation (3: 7-4: 14) follows by the description of Christ as the Son and His superiority over Moses (3: 1-6), the third exhortation (5: 11-6: 9) follows by the description of Christ as the Son of God and Heavenly High Priest (4: 14-5: 10), the fourth exhortation (10:19) -34) follows by the description of Jesus Christ as the Only and Perfect Sacrifice (10: 1-14), the fifth exhortation (12: 14-28) follows by the description of Christ as the Author and perfecter of faith (12: 1-3). By this it is quite obvious that both the admonishing part of the message (paraenetic) and the thesis (proclamation of the greatness of Christ) go side by side and there is no need to find out which part is the main one (some researchers try to do this). Moreover, the thesis part is presented very thoroughly. If the members of the community had previously been instructed in these truths, there would be no need to talk about it again.

The entire Epistle to the Hebrews, in which the author uses the Aristotelian approach (Thompson, 2008: 17; SBC, 2016: 1762), is replete with a description of the essence (nature) of Jesus Christ. He is the True Son of God (1: 1-14; 3: 3-6; 5: 5).

First, let's turn our attention to the first chapter of the Epistle. Already the first four verses, representing the Exordium, proclaim the divinity of Christ.

Jesus, being a prophet, stands above the prophets (1: 1-3). He is superior to them in His position (Matthew 11: 9-11). He is higher than them in content and completeness of revelations. He acted in the prophets who brought His word into the world (1 Peter 1: 10-11).

Jesus is not just a Prophet, $\mathrm{He}$ is the Son of God. The divinity of the Son is not only proclaimed in the message, but also confirmed by the attributes inherent in God.

In the 1st chapter of Hebrews (as well as in the 1st chapter of the Gospel of John) we find simple axioms in which the attributes of Christ are compared with those of God. The identity of the attributes of Christ and the attributes of God indicates the deity of Jesus. For example, Heb. 1: 2 (Jesus the Creator) cf. from Genesis 1: 1 (God the Creator) $\rightarrow$ Jesus is God; or Heb. 1: 3 (Jesus forgives sins) cf. with Mr.2: 7 (only God forgives sins) $\rightarrow$ Jesus is God. The topic of the divinity of Jesus Christ has been fairly well researched and presented by various researchers. In this work, we will bypass it and put more emphasis on Jesus as the Son of God.

So the Son is true God. Moreover, $\mathrm{He}$ is an obedient Son (Peeler, 2011: 6). The idea of the Son's obedience runs like a red thread throughout Scripture. He was obedient to His Father in heaven, being in glory (before His incarnation). The prophet Isaiah speaks of His greatness and holiness - Isa.6: 1-5 (cf. John 12: 37-41). The New Testament texts also speak about His humility and obedience - John 20:21, 1 Tim.3: 16, Phil.2: 6-11. The Son is obedient to His Father and on earth, during temptations and sufferings in the flesh - Heb. 5: 8-9, 10: 5-7, Matt. 26:42; John 12:27.

Let us pay special attention to the passage 10: 5-7 (quotation from Ps. 39: 7-9 to LXX): "Wherefore when he cometh into the world, he saith, Sacrifice and offering thou wouldest not, but a body hast thou prepared me: In burnt offerings and [sacrifices] for sin thou hast had no pleasure. Then said I, Lo, I come (in the volume of the book it is written of me,) to do thy will, O God. "

Doing the will of the Father is the meaning of the life of the Son. He Himself speaks of this, His life testifies to this, we read about this in the Scriptures (John 5:19, 30; John 17: 4; Matthew 26:42; 5:17). Hebrews 4:15 testifies that $\mathrm{He}$ is " ... tempted like as [we are, yet] without sin". If sin is disobedience to God, then the absence of $\sin$ is the fulfillment of the will of the Father.

The Son's obedience to the Father was manifested in His readiness for incarnation, in His attitude towards parents (Luke 2:51), in the readiness to take upon Himself the sins of people and to endure suffering (Matthew 3: 117), in the arrangement of life priorities (Jn. 4: 31-32), in giving up one's own ambitions, in sacrificial and dedicated service to the Father, and many others. others. We find similar thoughts in Daniels (p. 55). The phrases "My hour has not come", "The time has not come", My hour has come "are found more than once in the Gospel of John. This means that even the hours and moments of Jesus' life were passed under the control of the heavenly Father.

Let's see on the Hebrews 5: 7-9. Each verse is filled with evidence of the Son's obedience and reverence. Amy L.B. Peeler (2011: 171-174) says that one of the manifestations of the obedience of the Son of God is His prayer life, reverence for the Father, and willingness to suffer.

The phrase "with strong crying and tears unto him that was able to save him from death, and was heard in that he feared" testifies to complete contrition and humility. A similar phrase is used in Hebrews 12: 15-17, which tells of a complete, though belated, contrition before Esau's father. With tears, he asked his father to give him blessings.

The phrase "heard for His reverence (eu'labei /av)" is indicative of divine fear, consideration and respect in all circumstances (Cleon Rogers, citing Westcott and Michel, 2001: p. 806). Weeping petition, not self-will, God's fear, reverence for the Father are the qualities of an obedient Son.

Verse 5: 8 " Though he were a Son, yet learned he obedience by the things which he suffered" (kai / per wJ nuio \ve \# mayen a'f "w \{ne \# payen th $\backslash$ nu; pakoh $/ \mathrm{nV}$ ) is fundamental to the theme of true sonship and talks about the goal of each son - to patiently learn obedience to his father in different circumstances, and not to manage or manipulate him.

"And being made perfect, he became the author of eternal salvation unto all them that obey him" - v. 5: 9. Photius (Commentaries of the Church Fathers, 76) writes "... being made perfect - that is, having been recognized as perfect, and inexpressibly good, and humane for His suffering, cross and death". "teleiwyeilv" - to complete, bring to perfection. Jesus' perfection consists in maintaining integrity in the face of any challenge (Rogers, 2001: 806). Thus, the Son was perfected in His obedience. Was He imperfect? He was perfect before His incarnation. This text is about His perfection after incarnation (during temptation). Improvement doesn't mean imperfection. An example would be an athlete who has not lost a single competition in his career and was a winner in his sport in eve- 
ry age group. Moving from one younger group to an older one, he was ready to compete with the more mature ones. Why? Because he was "infected" with a passion for sport, because he had a goal, because he learned something new for himself every day, analyzed, benefited, trained. A similar example can be cited in relation to a person who connected his life with science. About Jesus it is said (Luke 2:52): " And Jesus increased in wisdom and stature, and in favour with God and man." To succeed in age means to go in development, in strength, in knowledge and wisdom ahead of your age, to be ready to enter a new age group ahead of time. Jesus has achieved the perfection in the flesh not so much by His special qualities (Heb. 2:17), but by the willingness to trust and obey the Father in all circumstances of life (note that the word teleiwyei $I v$ is a passive sacrament). An athlete will achieve significant results if he fully trusts the coach and follows all his instructions. A young scientist will reach maturity by listening to the good advice of a mentor.

The obedience of the Son of God to His Heavenly Father, the willingness to do all His will led Him to even greater glory. The sufferings of Jesus Christ put the final point in the perfection of the incarnate Son of God (refer to the phrase "the leader of their salvation made them through suffering"). Let's compare Heb. 2: 9 and Phil. 2:11 (Jesus entered the glory of the Father; Jesus glorified the Father and entered into His glory - Heb. 11:16). To the glory that the Son had before incarnation was added the glory after the incarnation of God's plan of salvation. After the suffering of Christ, all creation glorifies both the Father and the Son (the Son entered the glory of the Father) for the wonderful plan of salvation (Rev. 5: 814; esp. 5: 9 - they sing new song).

The Son's obedience to the Father not only brought Him to glory (Heb. 2: 9; $5: 10,6: 20$ ), but also led to the glory of those who were saved by Him (Heb. 5: 9; 2:10). In his later writings, Calvin noted that Christ's active obedience (from birth to death) and passive obedience (at death) together make us righteous before God (Seal, 2019: 43).

Notice Hebrews 2: 7-9.

A1. 7 h'la/ttwsav au'toln bracu/ ti par" a'gge/louv,

B1. do/xh` kai` timh `_e'stefa/nwsav au'to/n,

C1. 8 pa/nta u;pe/taxav u;poka/tw tw_n podw_n au'tou_. e'n tw_. ga ${ }^{\prime}$ u;pota/xai [au'tw'] ta $\backslash$ pa/nta ou'deไn a'fh ken au'tw' a'nupo/takton. nu n de ou\#pw o;rw_men au'tw'__tal pa/nta u;potetagme/naV

A2. 9 to $\backslash n$ de bracu/ ti par" a'gge/louv h'lattwme/non

B2. ble/pomen i'hsou_n dial to $\backslash$ pa/yhma tou_yana/tou do/xh`kai timh`_e'stefanwme/non,

C2. o\%pwv ca/riti yeou_u;pe\r pantolv geu/shtai yana/tou.

The above text says that as a result of suffering (this is also a manifestation of obedience to the Father - Heb. 10: 7), Jesus received glory and worship from those for whom $\mathrm{He}$ died. But $\mathrm{He}$ died for everyone. Text 2: 7-9 agrees well with 1 Tim. 3:16, Phil. 2: 6-11 and Luke 1: 46-47.

People who are saved through the suffering of Jesus Christ receive glory. They receive salvation (2:10), enter into the inheritance of God (2:11 - sanctified), become children of God and brothers of the Son of
God (2: 11-13), are freed from the power of the devil (2: 14), get rid of the fear of death $(2: 15)$, receive God's help (2: 17-18).

Verse 2:12 contains a quote from Psalm 21:23, a prophecy that says Jesus' suffering will lead to the glory of the saved. They will become children of God, brothers and at the same time children of the Son of God (Ps 21: 31-32; Is 53: 10 (posterity for a long time).

Hebrews 2:13 contains a quotation from Isaiah 8:18, which says that the children born to Isaiah will be proof of God's faithfulness to His promises. He promised to punish the northern kingdom of Israel and Syria, which attacked Judah (see Chapters 7 and 8). Which is exactly what happened. At the same time, Is.8: 18 has a clear parallel with 7:14 (see Matthew 1: 21-23), which refers to the immaculate conception and birth of the Son of God from the Virgin (Kharchlaa, 1990: 30; SBC, 2016: 810). This is evidenced by the context, as well as the word tFwa (sign) used in one place or another. As the children of Isaiah were a sign of God's victory over the enemies of Judah, so the children of the Son of God were a sign of their triumph and victory over their opponents (cf. 2 Thess. 1: 4-10).

Thus, verses 2: 12-13 in the context of Ps.21 and Isa.7-8, 53) can and even today can become an encouragement for a "tired" community, for a weakened believer.

Let's look again at Hebrews 2: 11-13. The saved become children of God and brothers of Jesus Christ. This means that their rights are fully protected. Both as brothers and as children - they are full heirs (Is.53: 12). Hebrews speaks of inheritance at least 10 times. The Epistle to Hebrews 1: 2,4 - twice speaks of Christ as the Heir (children of God are joint heirs: Rom. 8:17; Eph. 3: 6; Heb. 11: 9). Hebrews 1:14; 6: 12.17; 9:15 four times we speak of God's children as heirs. And at 11: $7,8,9 ; 12: 17$ we find examples of how different people treated the inheritance (Noah - 11: 7; Abraham - 11: 8-9; Esau - 12:17).

What, according to Hebrews, do the children of God inherit? - salvation (1:14), promises (6: 12,17; 9:15), glory (2: 7-18) and many others.

The thesis of the high position of people redeemed by Christ, who lost their identity with the Israeli people and lost all material goods on earth, given by the author of the Message, is certainly a strong argument in favor of the confession of Jesus in the context of the word of admonition (paranesis - 13:22).

Obedience is expected from the children of God (cf. 1 Peter 1: 1-15). This idea can be clearly seen in the letter to the Hebrews. They are required: attentiveness to the words of the Father (2: 1-4), trust in the Father (3: 7-4:14), the desire to be like the Father (striving for maturity) 5: 11-6: 9. They should cherish sonship (10: 18-31 (10:23)), as well as strive for holiness and keep grace (12: 14-17).

All these qualities were clearly evident in the life of Jesus.

Hebrews 12: 4-11 can be a generalization to the entire content of the Epistle. People who have turned to Christ are children of God and heirs of great promises (Rom. 8:32), which can be obtained by faith and obedience. Like any father, God punishes them for their own good. 


\section{Conclusions}

The author of the Epistle is addressing his letter to the community, mainly consisting of Jews. He puts his main emphasis not only on the High Priesthood and the Sonship of Jesus Christ. The subject of Jesus Christ's obedience to His Heavenly Father occupies a lot of place in the Epistle and is one of the key ones. The author shows that it was not the unfaithfulness of God, but the disobedience of the members of the community to the commandments of God that led them to punishment. The punishment, reflected in the persecution, caused a crisis of faith of some members of the community in Jesus Christ and turned them back - to Judaism. The message clearly shows the thought - it is not enough to confess Jesus Christ as the Son of God. It is important for the followers of Christ, the children of God, to live in complete obedience to the commandments. The Son of God, being obedient to His Father, is set as an example to follow for His followers. His humble and consecrated life led Him to glory. The dedicated life of His children will lead them, possibly through suffering on earth, to blessings on earth and to heavenly glory.

\section{REFERENCES}

Peeler, Amy L. B. (2011). You Are My Son': The Family of God in the Epistle to the Hebrews. PhD dissertation. Princeton, NJ. Mackie, Scott D. (2007). Confession of the Son of God in Hebrews. New Testament Studies, 53 (1) : 114-129. DOI: https://doi.org/10.1017/s0028688507000070

Carson D.A. \& Douglas J. Moo. (2005). An Introduction to the New Testament. Downers Grove, IL: IVP

Алсксандр Шумілін,

Бішкекський Біблейський коледж (м. Кант, Киргизстан)

e-mail: bukyrg59@gmail.com,ORCID0000-0002-3087-5292

\section{БІБЛЕЙСЬКИЙ ОБРАЗ ІСТИННОГО СИНІВСТВА У ПОСЛАННІ ДО ЄВРЕЇВ}

Тема синівства - одна з центральних в Новому Завіті. Іноді це простежується явно, але частіше побічно. Істинне синівство передбачає послух батькам i, як наслідок, веде до батьківського благословення. Цю істину автор Послання до Євреїв хотів донести до своїх читачів. Він зробив це на прикладі Ісуса Христа як Єдинородного Сина Божого. Той, будучи істинним, єдиносущним Отця, Сина, проявив повну і беззастережну слухняність, незважаючи на сильні спокуси і неймовірні страждання. Його послух Отцю призвів не тільки його Самого до слави, не тільки показав святу сутність і премудрість Самого Бога, а й призвів і веде до слави Його послідовників. Покликані Богом і врятовані Ним, ставши Його дітьми, в слухняності Богу мають уподібнюватися до Сина Божого, як Первородного. Тільки присвячене Богу життя веде людину до благословення. Фундаментом такого життя є віра в Ісуса Христа і життя за Його заповідями. Відступ від Нього і порушення Божих заповідей позбавляє людину благословення й благодаті.

Більшість дослідників Послання до євреїв приділяють більше уваги синівству Христа і Його первосвященству, і це важливо, щоб показати членам громади перевагу того, що вони мають в Ісусі над іудаїзмом. Однак мало хто підкреслює послух Сина Божого Його Небесному Отцеві і його наслідки, а також приклад цього послуху для послідовників Ісуса Христа. Автор Послання хоче показати, що не тільки сповідання Ісуса Христа Господом, адже і послух є гарантією благословення. Непослух членів громади спичинив їх Боже покарання, викликав кризу віри і призвів до відступництва. Справжній син - слухняний син.

Якщо в дослідженнях різних авторів і є будь-які згадки про послух Христа і Його приклад для Його послідовників, то вони дуже короткі й локальні. Тому завдання даного дослідження - більш глибоке вивчення Послання в рамках даної теми.

Ключові слова: Послання до Євреїв; тема послуху Небесному Батькові; Небесна спадщина; Обіиянки слухняним Божим дітям.

(C) Alexander Shumilin

Надійшла до редакції: 19.09.2020

Прийнята до друку: 12.10 .2020 